\title{
OF LOFTS, EVIDENCE AND MOBILE TIMES: THE SCHOOL PLAY AS A SITE OF MEMORY Sally Mackey
}

\begin{abstract}
How do we remember past arts events? What forms of tangible evidence exist to demonstrate such memories and what meanings can be taken from the archiving of artefacts in contemporary times? The research discussed in this article showed that a school production taking place twenty-years ago is remembered as a significant event in the lives of its participants with physical objects associated with the production stored and preserved by most of the original company members. What is the role or function of this memorabilia in their lives? How can the hoarding of such evidence be interpreted? In pursuing these questions, I interrogate emotional responses to objects from the past - by way of a visit to a loft - and ask why material artefacts from the past appear to retain such importance, particularly for those acclimatised to a 'virtual' age. An interpretation of this evidence-demonstration is offered in the final sections of the article - that we archive and store certain moments of our histories to counterbalance an increased mobility. These collections perhaps represent 'sites of memory' (Nora 1989, 7-29) in lives characterised by movement.
\end{abstract}

The school play is an aspect of drama education not traditionally given much research attention. It has suffered, perhaps, from being doubly-relegated. First, it has not always been valued as a serious part of school-based drama education. Second, it is often considered theatrically second-rate, lacking professional-level skills in direction, design and performance. These relegations may have left the school production under-researched. After the 1980s' schismatic debates in the UK about the purpose of drama education (Bolton 1984, 1-75; Hornbrook 1989, 3-54; Byron $1986,1987)$, the study of theatre and production began to regain favour, however. More recently, particular schemes in the UK have helped elevate the status of school production work. The National Theatre's Connections programme, for example, invites contemporary playwright such as Mark Ravenhill, Dario Fo and Sarah Daniels, to write specifically for schools and youth groups with final performances staged at the National Theatre. Research has followed with John Deeney (2007) using the youth-based Connections programme to challenge ideas of citizenship. In this research article, however, an example of a school production is used to debate evidence, artefacts and remembrance.

The research was initiated by a visit to my loft (or attic) in which is stored a memorial of a school production. The article begins with a reflection upon the effect of material remains in my loft - including the memorabilia from the school production I directed. This provoked an interest into the affective qualities of physical artefacts, particularly in a 'virtual' age.

\section{Lofts, artefacts, emotions and anniversaries}

We had cause to empty and refill our loft recently which entailed opening several boxes to explore contents; there was an intention to discard items that were now beyond our interest. Lofts are consummate sites of personal memory-evidence. A loft 
is a form of archive and a place which, on the whole, remains highly personal and private. As well as a site for objects that have no other appropriate location for most of the year, such as seasonal decorations, many comprise storehouses of one's past with iconic artefacts that reference a life. I consider ourselves to be fortunate to have such a space.

Lofts can be uneasy places; I have a paradoxical relationship with mine. It is the site of a personal collection, not one I want on display, but containing much that I am not able to discard (dolls, 'wedding box', meaningful clothes, school exercise books, old pictures, guitar-that-went-to-university ...). There is security in knowing my past is safely stored. Yet, by contrast, being in the loft and physically handling those artefacts I find unsettling. It prompts emotional vulnerability. There is a connection with past times provoked by this tangible reminder that, because of the immediacy of material contact, seems particularly evocative. (In looking through a box containing a long skirt, I return to making it, aged 13, with my mother guiding; I handle the skirt reverently.) There is something of Roland Barthes' punctum here: an effect of looking at certain photographs 'which rises from the scene, shoots out of it like an arrow, and pierces me'. Such punctuated moments are a 'wound', a 'prick'. 'A photograph's punctum is that accident which pricks me (but also bruises me, is poignant to me)' $(2000,26,27)$. Barthes talks of two-dimensional photographs rather than threedimensional objects (although a photograph may be perceived as an object in itself, of course). Many are not personal to him, although the heart of his text is a mourning of his mother by way of photographs. These loft objects are, on the whole, personal, physical objects (with some photographs inside scrapbooks) and rummaging through them has something of the effect of Barthes' photographic punctum upon me; I feel a wound, a prick, a poignant bruise. It is an emotional moment. The loft-paradox is that I am reassured by the artefacts that are a safe archive of my life, yet seeing and touching them invokes a swift onset of many emotions that leaves me feeling somehow exposed - or wounded, in Barthes' terms.

I'm not sure which emotions I experience: sorrow, grief, envy, joy, jealousy, pity, remorse, guilt, shame, pride or wonder. The individuation of emotions has been quite usual in many forms of associated critical literature historically (e.g. Peters 1974, 177-178) with some being further apportioned into categories such as 'passive' and 'active' (Sartre 1971, 68-70) or 'agent-directed' and 'non-agent-directed', for example (Pitcher 1965, 327). The loft artefacts evoked a form of amalgamated emotional experience, however, a drawing together of many emotions, and in a highly concentrated moment. When I confront the relics in my loft, it would be difficult to name the exact emotions that provoke that sense of raw vulnerability. Handling the skirt made by a 13-year old former self arouses some kind of fusion of sorrow, joy, pity, love and pride maybe, but it would be hard to isolate or categorise these emotions. Perhaps that is why the experience is unsettling: it is a concentrated, emotionally-complex hothouse.

Elaine Scarry describes an emotional response - in this instance to something beautiful - which describes something of the 'hothouse' effect in the loft: '[It] fills the mind ... [causing] us to gape and suspend all thought' $(2006,29)$. It is her interpretation of the relationships between humans and artefacts that offers further insight into the emotional response to my loft objects, however. In her text examining pain, war and torture (1985), Scarry emphasises how difficult it is to express powerful emotions (pain, in this instance.) She suggests that we find a form of replacement for such concentrated and dense expression by habitually projecting meaning and aliveness onto external artefacts: 'the imagination works to distribute the facts and responsibilities of sentience out onto the external world' $(1985,325)$. Through using our imagination, we pass on the 'privacy and problems' (285) of our emotional 
response, or sentience, to external objects because we do not have the capability of expressing them within ourselves. (Scarry describes sentience as 'the felt-fact of aliveness that is often sheerly happy' (22).) An almost inexpressible collection of emotions are thus managed, by projecting them onto objects. We use artefacts as an enlarged repository for complex emotional responses, she is suggesting. This act of the imagination facilitates an expanded emotional realm, beyond our own body:

A material or verbal artifact is not an alive, sentient, percipient creature, and thus can neither itself experience discomfort nor recognize discomfort in others. But though it cannot be sentiently aware of pain, it is in the essential fact of itself the objectification of that awareness; itself incapable of the act of perceiving, its design, its structure is the structure of a perception. ... [It is] mimetic of sentient awareness. (289; emphasis in original)

She is saying here that of course, such artefacts do not have feelings or are alive yet they objectify sentience for us providing us with a further vessel upon which we can project complex, layered emotions; it allows us some form of release.

This projection of emotional 'excess' onto artefacts, by way of the imagination, contributes something towards understanding the punctum or the amalgamated emotional response of the loft experience. The loft objects provoked emotions and, in turn, became the site for projected sentience, a sentience which they had caused. These objects are the carefully stored archives of a past; they are a source that then becomes the focus and receptacle for the projection of a 'wounding' collation of swiftly-provoked emotions. Scarry talks of a chair, where we might hurl the remnants of a leg chair against a wall because the chair has caused us pain when it broke. The chair leg is momentarily the artefact upon which emotions (of pain) are projected $(1985,296)$. Similarly, these loft objects become the focus for feelings initiated by memories. They are handled and reverently repacked and replaced rather than hurled away. As Scarry suggest, they may well be 'mimetic of sentient awareness' and offer a focal point upon which a plethora of emotions - difficult to express elsewhere - are projected.

Thoughts about loft artefacts and the responses they stimulated contribute to this article as part of what it is to evidence long-term memories and how tangible artefacts are both treasured and emotive. More specifically, however, amongst the loft goods re-examined was a suitcase full of memorabilia of a school production I once directed. The suitcase itself is a relic, one of two cheap plastic containers bearing a Snoopy cartoon and bought for the three years of travel to and from university. On rifling through the contents in 2009, I recognised that it was the twentieth anniversary of this suitcased school production, prompting speculation about how others remembered the event. I valued these remnants of a much-loved school production, experiencing a kaleidoscope of recollections imbued with a sense of mourning yet celebration. Would others have similar hoards and how would they respond to such an archive? I recognised this as an interesting opportunity for research into the long-term memories of arts events and attendant material evidence. 


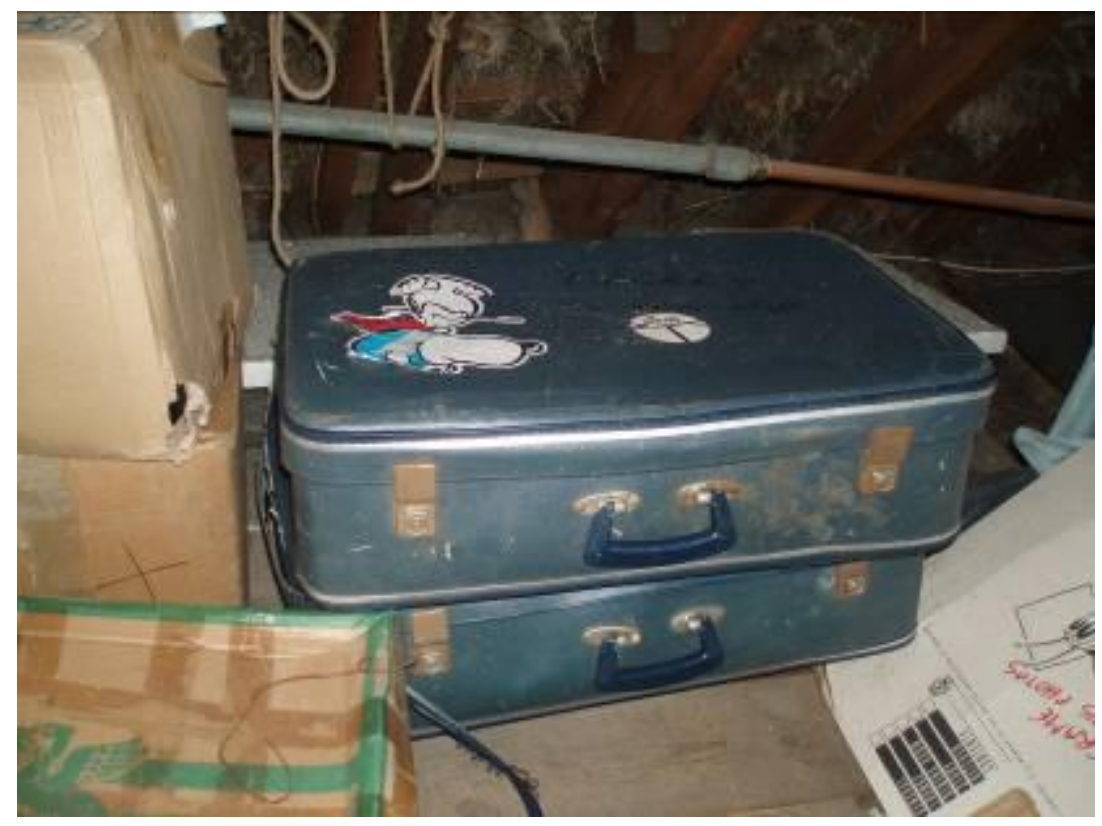

Roade School's Godspell (a musical theatre piece by Stephen Schwartz popular in the 1970s and ' 80 s) comprised a cast of around forty $13-18$ year olds with several others as band and technical support. There were three stages in its life from autumn 1988 to autumn 1989: two sets of school performances; the UK's National Student Drama Festival (NSDF) in Cambridge where it received a company award; a performance sponsored by Radio Northampton that sold out at the local 1200-seater Derngate Theatre. Such an extended life was unusual for a school production and it yielded a range of 'collectable' mementoes. My tangible traces of this event - the contents of the suitcase - comprise comprehensive scrapbooks, copies of Noises Off (the daily newspaper of the NSDF), a cap, mugs, t-shirts and, bizarrely, the print plate from the UK's The Sunday Times of the page with the 1989 NSDF review. The suitcase in the loft prompted a summer of resurrecting people and memories.

\section{The archives of a school play}

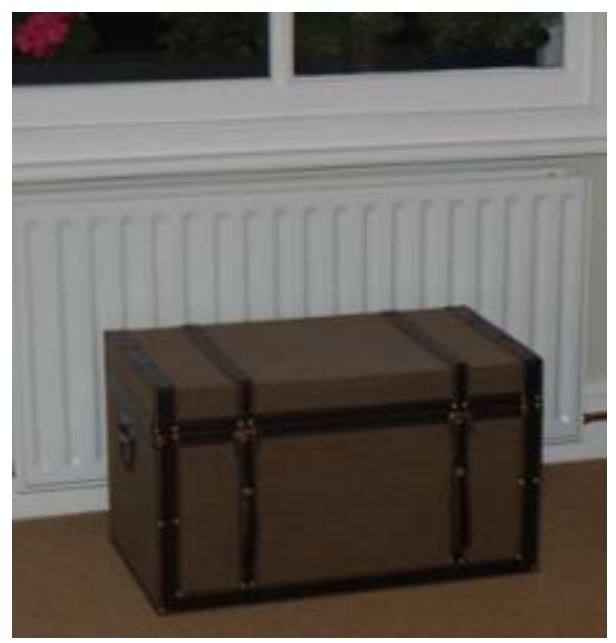


In Critical Events in Teaching and Learning (1993a), Peter Woods used four arts education events to make a case for the importance of artistic 'critical events' in the lives of young people. A professor of education, Woods' interest was in the sociology of learning and teaching. In this work he was influenced by the current articulations of the importance of the arts in the education of young people (e.g. Abbs 1987, Robinson 1982, Ross 1989) at a time when many fought for the arts to be fully represented in the imminent UK's National Curriculum. Specifically, Woods suggested that out-of-the-ordinary arts education experiences have a particularly effective impact upon young people and increases the 'art of learning' (1993a,142) leading to enhancement of pupils' creativity, emotional development and confidence. His was a theory of aesthetic learning (1993b).

Woods used the Roade School Godspell as one of his four case studies. Having seen the production at the Derngate, he undertook his research retrospectively, using 'historical ethnography': 'the exploration of events that have occurred in the past, using qualitative, naturalistic methods that aim to explore meanings and understandings and re-create cultures and contexts ...' (1993a, 157). Citing Kelchtermans (1991), he emphasised that events cannot be critical until they have taken place; it is not possible to 'foresee' critical events (1993a, 157). Woods undertook the research within a year of the final stage of the event. He makes a highly convincing case for student (and staff) development based on the evidence he collected (letters, interview transcripts, newspaper items and so on).

Woods suggests this was an important and effective experience at the time. What remains of this 'critical event', however, and how is it evidenced in the lives of those youngsters who took part?

With the help of social networking sites, I tracked down approximately 30 of the company with 23 completing and returning a questionnaire. The questions were few: What are your immediate thoughts when you think of our production of Godspell? Were there specific values, competencies and skills that you gained from that production experience that you can remember? Which performances can you remember and why? How far does this production figure in your memory of school life? Do you have any 'tangible' artefacts from then? If so, what and where are they? I asked, too, if each person could summarise their 'life' in the years since school. (I still know a few ex-pupils. I had left the area in 1992, however, and lost contact with most of the company.) Whilst originally this was simply out of a desire to know more about them, the distances travelled from Northamptonshire (a county in the middle of England) struck me as unexpected and contributed to the debates I began to consider about how we retain significant events as sites of memory, discussed further below. 


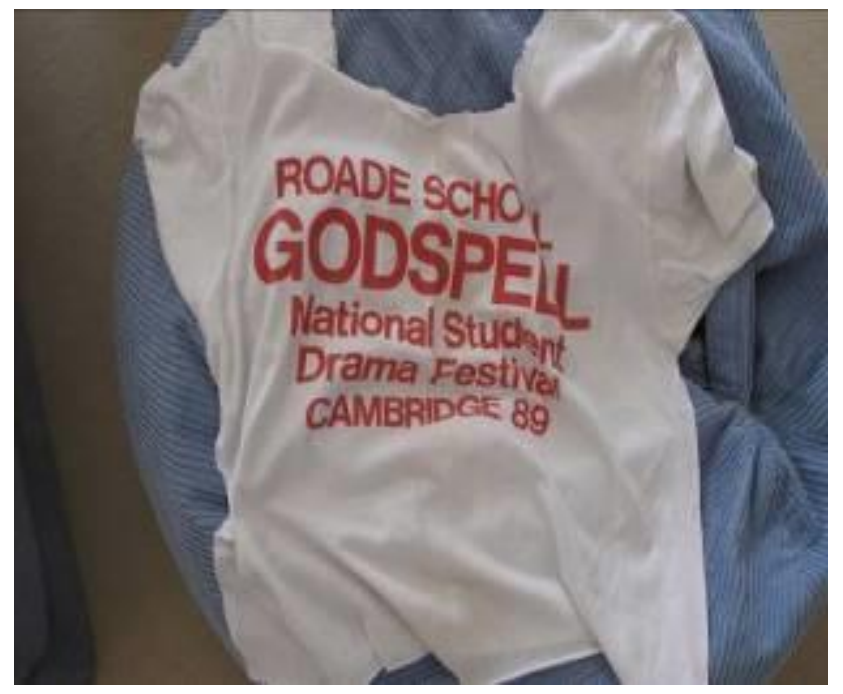

Recognising that people were interested enough to reply was affecting and emboldened names from the past in my Inbox took priority over quotidian work emails. As I read each email, I was aware of these now-adults struggling to recall their young selves and say faithfully what they felt they gained from the Godspell experience. One ended her response in tears, she said, remembering emotions from twenty years ago. Several believed that they had gained increased confidence and self-esteem, a sense of community, a nurturing of pride in achievement, discipline and attention to detail and, of course, performance skills which some went on to use in their later careers. These responses support Woods' 'immediate' findings in 1990/1 and, indeed, support the claims for arts education that have been made in earnest for forty years. A few described the event as a defining moment in their school lives indicating a moment of ritual as they made the transition from child to young adult. Some comments were unexpected. One spoke of 'learning how to deal with loss' at an early age, for example. He had been 13 when we started the production. As each stage ended, the company - including myself - experienced a period of mourning for the project, perhaps familiar to many involved with successful and beloved performance work. Interestingly, he appeared to find that process a useful learning experience. All found some way of expressing the event as a key - and most positive - memory. One spoke of their pride in being 'kids from a comprehensive school' doing so well at an NSDF. There was an assumption from all that there were long term benefits, although one or two found it difficult to specify how. All the responses were pleasurable to read. I had hoped for the positive and, as a former teacher, my first response was a profound reassurance that these ex-pupils felt the project had offered them something worthwhile, remembering it as an important event in their lives. 


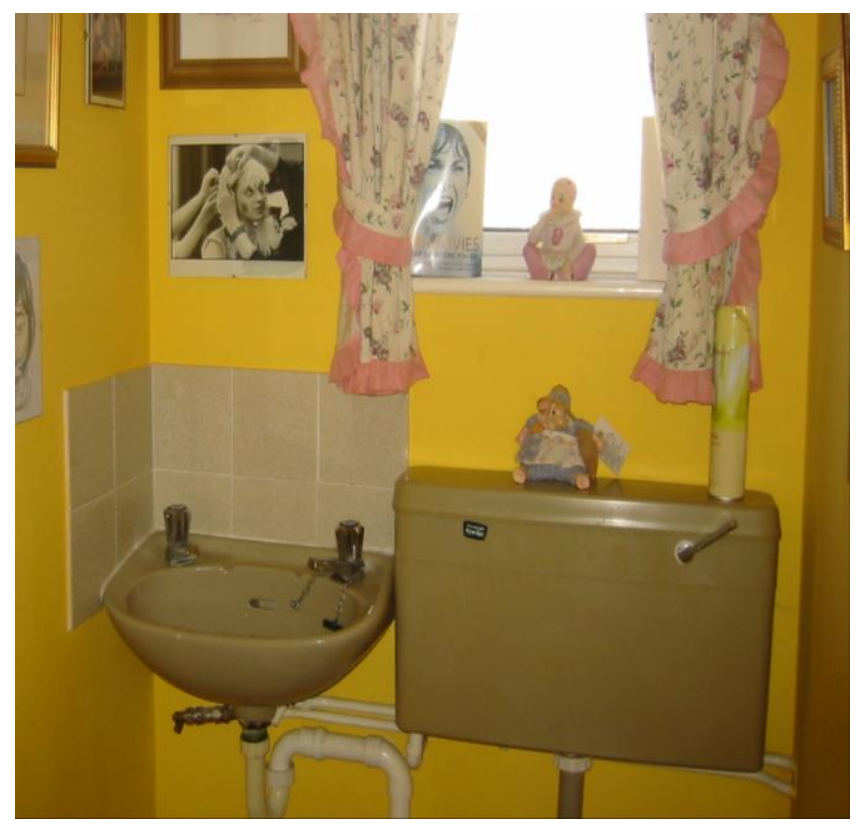

What became particularly interesting in the Godspell research process, however, was noting the evidence that remained, the tangible artefacts, the lasting, physical, demonstrable signifiers of the event.

Claudine used the tee shirt with the neck cut away in dance training for many years and still has it in a drawer. She 'can't bear to throw it away'. Mel has her scrapbooks inside the trunk by the radiator in her lounge and was devastated when they went missing for some years. Dieter had the Godspell mug in his 'mug cupboard' although the writing wore off long ago. He knows that the writing was there, so it is still his Godspell mug and he is reminded of the show when he uses it. Ross has one of the posters framed and hanging on a wall in his house; it bothers him that he can't remember who created the poster as if he wanted to recall minute details of the event. Laura spoke of a photo that appeared in the UK's Times Educational Supplement at the time. She had written and asked for a print from the paper and has it framed, hanging in her downstairs toilet. Several participants have the videos although no longer the video players to play them. Rescued from his mother's loft, Matthew has the programme, poster, photographs and other articles in the bottom drawer of his chest of drawers and said, 'I'm not a great hoarder ... but these are too important really.' Ironically, Peter Woods' chapter has itself turned into an artefact. Kevin still has a copy. He recalled first reading it at university and how it inspired him with a sense of achievement. Along with many other items, one member of the company has letters I sent to the cast after the productions in a suitcase under his bed. They meant a great deal to him, he says, as he 'wasn't used to praise in his house'. He retrieves them when he needs reassurance. He ended his questionnaire with 'I'm off to get them out now.' Despite shortage of space in urban flats or partners who don't sympathise with such keepsakes, there seems a determination to retain these artefacts. (Kirsty packed up her flat when she moved to Los Angeles but her Godspell mementoes are safely in a box in her father's office.) Whilst undertaking this 'survey' for research purposes, it was affecting to know these relics remained and, like my own in the loft, were regarded as important. There was a similar sense of emotions being hard to express and perhaps being projected onto these artefacts, as Scarry suggests. 


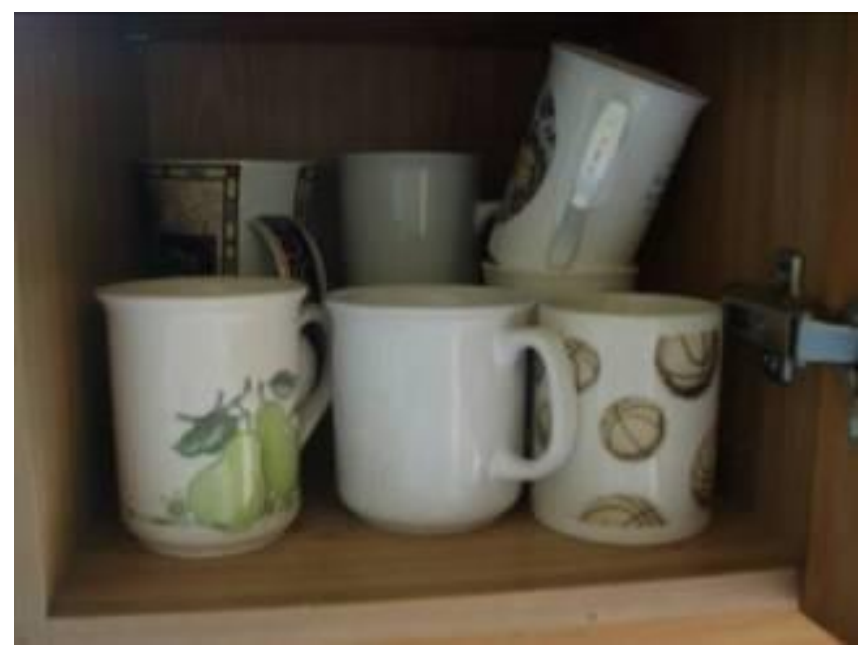

My interest in these tangible remains arose partly because of the loft-experience discussed above and partly from an interest in how material matter fares in virtual times. Responses from the company to memorial artefacts were similar to my reaction to my Godspel/Snoopy suitcase contents. These tangible objects were highly valued. Yet this is a generation that has absorbed social networking as a quotidian form of communication and storage; the virtual is probably unquestioned. Contacting past and present friends takes place primarily through the net; photographs are stored in i-pads and displayed on Facebook. Indeed, ironically, I made contact with these ex-pupils virtually and the questionnaire was disseminated by them through their Facebook sites. Old photos of the show can be found on some of these sites, I was told.

Such virtual reliance has been anticipated, of course. Derrida predicted an electronic archive fever, prophesying that electronic communication '...is on the way to transforming the entire public and private space of humanity, and first of all, the limit between the private, the secret, and the public or phenomenal' $(1995,17)$. Our archives were to be virtual and public; Facebook sites and YouTube clips appear to have proved him right. Paul Virilio made a cognate prediction, forseeing the demise of 'the real' and a loss of plenum (space filled with matter) (1991; 1994). He envisaged cities with no physical communities; tangible matter would decrease in importance as technological potential increased. Although cities remain full of human occupation, one could argue that the twenty-first century has indeed witnessed a loss of plenum. The web 2.0 explosion has dominated the first decade with a remarkable emphasis on the ordinary person displaying their lives virtually which, it could be argued, replaces 'matter'.

With this profusion of the virtual, it seems curious, therefore, that material objects maintained such importance to the Godspell company. Why is the tangible still privileged and revered as indicated by these small caches of memorabilia? Perhaps it is partly because of such 'easy' virtual contact that the material and tangible exerts a power. These artefacts are 'real', they are Virilio's 'matter' and maybe unusual in lives that store less. They may well be valued more as a result, as 'relics' from the past that can be physically handled, invoking a sentient connection with the past. Carolyn Steedman debates this point about archives, albeit from the perspective of a historian researching old documents. She describes archives as 'places in which the past (which does not now exist, but which once did actually happen; which cannot be retrieved, but which may be represented) has deposited some traces or fragments' $(2001,69)$. She refers to archives, too, as a place of dreams (although, again, this is in the context of a historian dreaming of a past not witnessed by any living). It is in 
the holding and touching of past documents or fragments that the excitement arises, she suggests, describing this as 'psychical phenomenology'. She relays, affectingly, a story of a historian pausing before undoing a ribbon as he pondered that this ribbon may not have been tied or untied in 150 years (81). There is a psychical reaction to the phenomenological process of being in the presence of, and handling, archival remains. Solid, material traces of the past provoke a distinct emotional response.

Of additional interest for considering the effect of the Godspell memorabilia, Steedman describes archive visiting as:

emblematic of a modern way of being in the world ... expressive of the more general fever to know and to have the past. Wanting the past can be attributed to certain turns of thought by which individual narratives of growth and development (particularly narratives of childhood) have become components of what we understand a modern self to be. "History" is one of the great narrative modes that are our legacy from the nineteenth century .... (2001, 75)

Steedman is referring to the now familiar habit of 'modern autobiographical narration' (75) increasingly recognised towards the end of the last century as self-reflexivity or the 'autonomous monitoring of life narratives' (Lash 1994, 115). There is an assumption now, Steedman suggests, that 'nothing goes away' $(2001,76)$ and all our past is important in the formation of the narrative of the self. The retention of archives that mark a notable period in childhood or adolescent years, as the Godspell archives do, may well contribute to the annotation of a past then. Such additional relevance, a record of childhood and adolescence, reinforces the potential of these archives to prompt emotional responses.

Steedman's account of the 'dust' of archives explains something of the power of the Godspell physical artefacts. Handling fragments of the past is a moment of psychical phenomenology. The location, use and memories of these objects over twenty years were myriad and the weight of affect attached to these objects, marked. The company's responses were similar: none of them wished to throw away these items and they all demonstrated a vivid emotional response to them. They appeared 'pricked' by the objects. Feelings were sometimes difficult to express. Quite possibly the artefacts were used as a focus for complex emotions, as Scarry suggests: one went to search out the letters he received and another was intending to take a trip 'home' to access her collection in her parents' loft. Where objects had been lost, there was sorrow. A preservation of tangible evidence seemed important to these company members, perhaps as part of narrating the self from childhood. Whilst virtual communications have encouraged certain forms of contact and indeed storage (including scanned old photographs), there seems an appreciation for 'the real'. The qualities of the tangible seem prized by these ex-pupils. The effects of their memorabilia might well be compared to the concentration of emotions and 'poignant bruising' that I experienced in the loft. It does not seem enough to access old photographs on contemporary Facebook accounts (as one person implied); it is the actual presence of the objects that date from a historical period and in one's own possession that take precedence. 


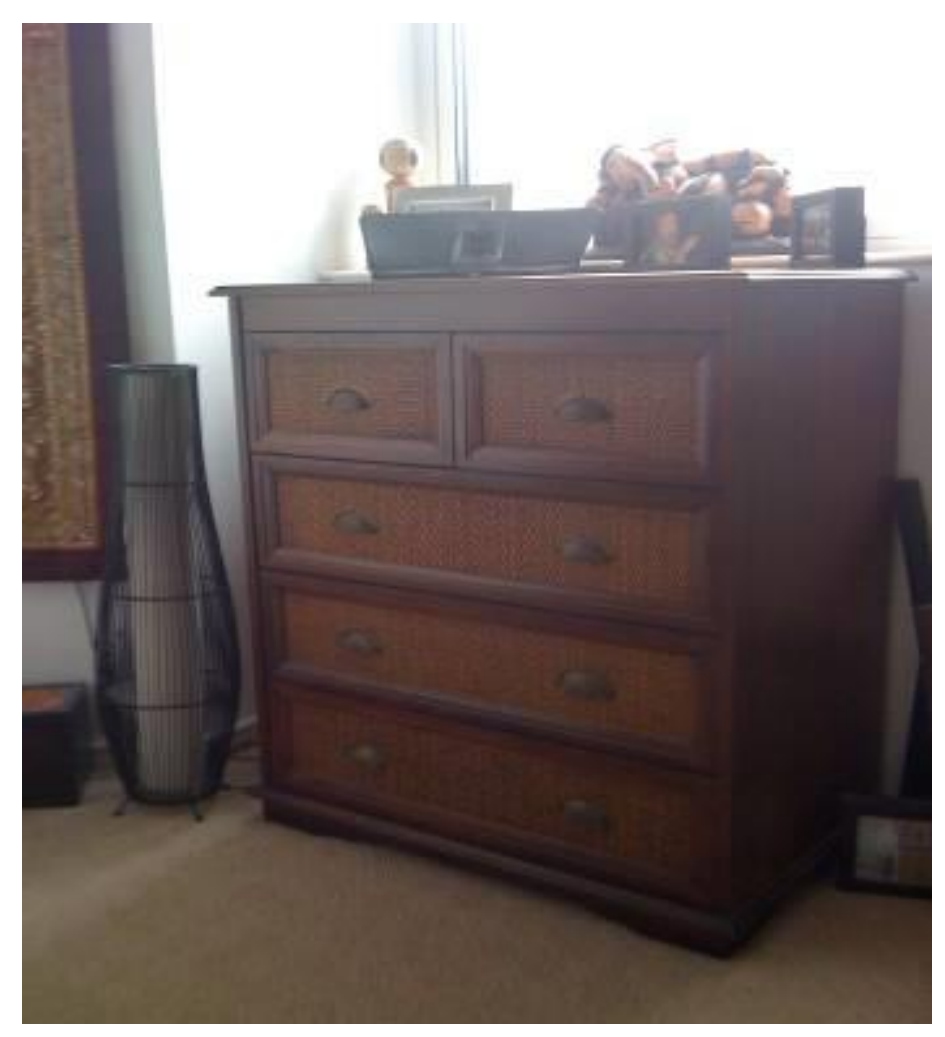

\section{A school production: sites of memory and liquid modernity}

Discovering the response to physical fragments that reside in trunks, boxes, lofts and mug cupboards implied a sanctity and reverence for such remains in a time dominated by the non-physical and virtual communications. How could this be interpreted further however? What might such reverence reflect? The Godspell evidence offers an example of how we memorialise and archive our lives, possibly as a response to increased mobility and 'acceleration' of the past, and privileging physical artefacts over the virtual. The remains of evidence suggest physical 'sites of memory'. This section of the article, then, takes research into the long-lived, affectual evidence of a warmly remembered school play into debates about the mobility of 'liquid modernity' and the creation of notarised sites to valorise memories.

In 1989 Pierre Nora suggested that we create special 'sites of memory' because there are no longer 'real environments of memory'. He attributes this lack to the 'acceleration of history' $(1989,7)$, that we have no time to mark key moments of history as once we did. We have accelerated the past, such that we live increasingly in the contemporary present. One consequence, Nora claims, is that we no longer ritually archive our lives. He argues that sites of memory are needed because we do not have the time for spontaneous memory. So, 'we must deliberately create archives, maintain anniversaries, organize celebrations, pronounce eulogies, and notarize bills because such activities no longer occur naturally' (12). We need 'commemorative vigilance' (12) or history will sweep away our memories, he argues. I was reminded of Nora's argument on receiving the information about the various Godspell 'archives'. Have we been creating material archives - deliberately or otherwise - as some kind of resistance to the acceleration of the past and, perhaps, our mobility? Quite possibly, the increase in electronic storage - discussed above - 
represents one form of deliberate site and meets Nora's request that we should explicitly commemorate. From the response of the Godspell company, photos of the past on Facebook sites do not have the impact of the material artefacts which are clearly revered because they are physical traces.

Nora's recommendations to notarise and construct key events, he suggests, act as a response, antidote or resistance to the mobility or fluidity that is perceived by many as central to contemporary life. Zygmunt Bauman describes such a life as liquid, 'a precarious life, lived under conditions of constant uncertainty' (2003, 2). Bauman's theory of 'liquid modernity' (2000) captures something of the recent extreme in the sociological and philosophical zeitgeist, emphasising a post-globalised world of psychological instability and physical mobility. How does this (controversial) theorising of liquid modernity affect the research into the memorabilia of the 1988-89 Godspell company, however? How mobile have they been, for example? If I am suggesting physical artefacts might represent a constructed site of memory in contemporary, mobile, relocating lives, how does the mobility of Bauman's liquid modernity fit the last twenty years of existence for these ex-pupils?

I was surprised by the travels of the cast, the great majority of whom have a parent or parents still living near Northampton. Of the thirty I know of, only four live in the area and all four have lived elsewhere in the intervening years, one spending years in two Australian cities before returning to live close to his parents. Eight of the thirty have lived outside the UK and several more have 'travelled' for periods of a year or so. Four still live outside the UK - in the United Arab Emirates, Hong Kong, Los Angeles and Spain and one was in the process of moving to Texas. The remainder live in various parts of the UK with four in London. Approximately $80 \%$ have lived in more than one area since leaving Northampton, excluding university and, if in a major city, have lived in several different parts of the city. Roade was a rural comprehensive (non-selective) school in an ethnically non-diverse area of England. The pupils attending Roade School were virtually entirely from socio-economic groups B - D. ${ }^{1}$ Parents' jobs ranged from middle management to semi-skilled manual workers. The Godspell company members were from families mostly situated in B-C2. The majority of the pupils were in the top $50 \%$ of the 'banding system', where subject lessons were divided up according to aptitude (English, Maths and Languages). Approximately $90 \%$ of the thirty I have heard about went onto some form of higher education receiving degrees or, occasionally, diplomas. Their current jobs range from teaching to directors of small companies; some work part-time in a range of occupations whilst children grow. Socio-economically, this group is more likely to now be B-C1.

All the travelling or relocation by these ex-pupils has been 'chosen' and has been undertaken for pleasure, study, work or at the behest of partners. Roade School was not a school for those in the top income brackets; it was a non-selective comprehensive school with a broad socio-economic intake. Nonetheless, it is certainly possible to argue that these 30 -somethings represent the mobile liquidly modern. Many have moved frequently, and out of choice. That option is available to them because of education, supportive family backgrounds (on the whole), aptitude and the affluence that accompanies good jobs.

With such mobility, it might be argued that a construction of sites of memory is relevant in these ex-pupils' lives. Perhaps such sites of memory do offer an antidote to, defence against or simply response to the maelstrom of fluidity purported to comprise modern life. If we no longer inhabit lives where rituals of celebration and commemoration of our history are implicit, as Nora argues, then to explicitly notarise, mark, recognise and retain particular events or moments from our biographies is an 
alternative. Key memories of events - anticipated rituals or maverick happenings might well be determinedly held sacred, perhaps as a replacement for the continuous belonging that was part of a more sedentary, located and historically-situated existence. The use of a 'white' mug, a suitcase under the bed or a picture in the downstairs toilet may represent commemorative vigilance, in this instance of a childhood past.

\section{Concluding thoughts}

The research has led to a theory suggested by artefacts retained from the Godspell event. Godspell could probably be described as an 'enhanced' school play experience because of the length of its life and its success beyond the school location. Even so, discovering that participants retained such evidence of the event, and despite moves around the world, has been surprising. This production developed the young people's 'art of learning', Woods convincingly argued in 1993. It may well also have shifted a perspective on life such that their adulthood has benefited in some way. Most of the participants would claim so, although this might be hard to directly 'prove' in many cases.

What is explicitly demonstrable, however, is the safeguarding of mementoes that memorialise and archive a school play from twenty years ago. I suggest these comprise a constructed, materially represented site of memory that celebrates a key moment from a biography, an event that amassed great importance for a year or so in teenage years. This would support Nora's premise. Where we do not inhabit and ritualise well-trodden, habitual and long-familiar environments because of our mobility - and these 35-40 year olds have indeed been mobile - is there an increase in the archiving of notable life-episodes? Do we more determinedly hold onto significant or critical events? Do we memorialise them, with or without hagiography, ${ }^{2}$ such that we offer commemorative vigilance and, by so doing, stabilise moments in a liquid life?

Certain representations of cultural memory are virtually displayed, particularly in the Facebook storehouses of photographs. These offer one form of memory site, no doubt. It is the retention, preservation and emotional response to the physical mementoes, the tangible, material artefacts, however, that has been particularly unexpected. Lofts, suitcases, boxes, trunks, chest of drawers, mug cupboards and toilet walls are physical, non-virtual sites of memory. These ex-pupils could not always articulate their response to these sites, reminiscent of my own complex reaction to the loft objects. Perhaps they too have a paradoxical relationship to such sites. Scarry's interpretation of how we habitually project emotions onto artefacts as a means of managing inexpressible feelings - or poignant bruising - offers some explanation for our reaction to such objects as memories are triggered. Steedman's account of visiting an archive as psychical phenomenology when we dream and pause in the face of relics from the past increases an understanding of why we value such material evidence. These carefully retained objects are quite possibly an annotation of a moment in life worth notarising and retaining as a particularly affective site of memory in mobile lives. 


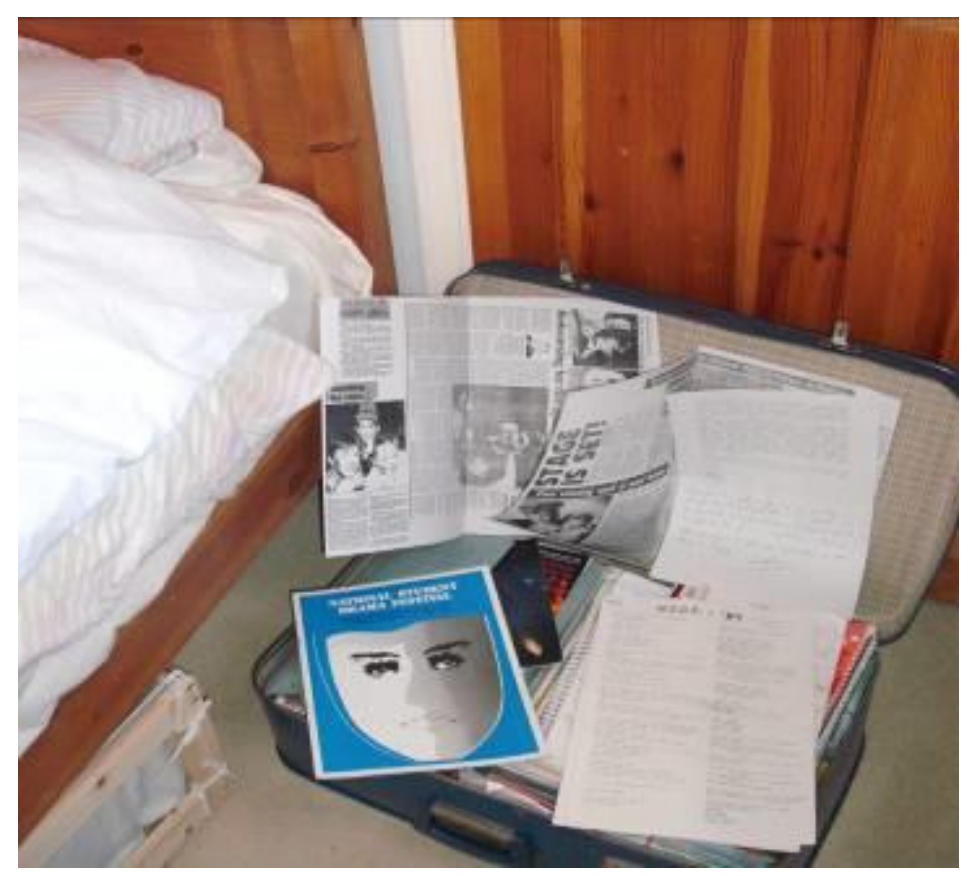

\section{References}

Abbs, P. 1987. The Living Powers: the arts in education. Lewes: Falmer Press.

Barthes, R. 2000 [1980]. Camera Lucida. Trans. R. Howard. London: Vintage

Bauman, Z. 2000. Liquid Modernity. Cambridge: Polity Press.

Bauman, Z. 2003. Liquid Life. Cambridge: Polity Press.

Bolton, G. 1984. Drama as Education. Harlow: Longman.

Byron, K. 1986. Drama at the Crossroads, Part 1. 2D 6.1:2-15.

Byron, K. 1987. Drama at the Crossroads, Part 2. 2D 7.1: 4-25.

Deeney, J. 2007. National causes/moral clauses?: the National Theatre, young people and citizenship. RiDE: The Journal of Applied Theatre and Performance 12. 3: 331 - 344.

Derrida, J. 1995. Archive Fever: a Freudian impression. Trans. E. Prenowitz. London: The John Hopkins Press.

Hornbrook, D. 1989. Education and Dramatic Art, Oxford, Blackwell.

Kelchtermans, G. 1991. Teachers and their career story: a professional development. Paper presented at the Fifth Conference of the International Study Association on Teacher Thinking, September 23-27 in Guildford, UK.

Lash, S. 1994. Reflexivity and its doubles: Structure, Aesthetics, Community. In Reflexive Modernization: Politics, Tradition and Aesthetics in the Modern Social Order, ed. U. Beck, A. Giddens and S. Lash, 110-164. Cambridge: Polity Press.

Nora, P. 1989. Between Memory and History: Les Lieux de Mémoire. Representations 26, Spring: 7-25.

Peters, R.S. 1974. Psychology and Ethical Development. London: George Allen and Unwin. Pitcher, G. 1965. Emotion. Mind 74: 326-346.

Robinson, K. (ed.) 1982. The Arts in Schools: Principles, Practice and Provision. London: The Calouste Gulbenkian Foundation.

Ross, M. 1989. The Claims of Feeling. Lewes: Falmer Press

Sartre, J-P. 1971. Sketch for a Theory of the Emotions. Trans. P. Mairet. London: Methuen and Co. Ltd

Scarry, E. 1985. The Body in Pain: the Making and Unmaking of the World. Oxford: Oxford University Press.

Scarry, E. 2006 (1999). On Beauty and Being Just. London: Gerald Duckworth \& Co. Ltd. Steedman, C. 2001. Dust. Manchester: Manchester University Press.

Virilio, P. 1991. Lost Dimension. Trans. D. Moshenberg. New York: Semiotexte. Virilio, P. 1994 [1988]. The Vision Machine. Trans. J. Rose. Bloomington, IN: Indiana 
University Press.

Woods, P. 1993a. Critical Events in Teaching and Learning. London: The Falmer Press.

Woods, P. 1993b. Towards a Theory of Aesthetic Learning. In Educational Studies, 19.3: 323-

328.

\section{Notes}

1 Socio-economic groups are described as follows for market research purposes:

A- Higher managerial, administrative, professional e.g. Chief executive, senior civil servant, surgeon

B - Intermediate managerial, administrative, professional e.g. bank manager, teacher

C1- Supervisory, clerical, junior managerial e.g. shop floor supervisor, bank clerk, sales

person

C2 - Skilled manual workers e.g. electrician, carpenter

D- Semi-skilled and unskilled manual workers e.g. assembly line worker, refuse collector, messenger

E - Casual labourers, pensioners, unemployed e.g. pensioners without private pensions and anyone living on basic benefits

(http://www.marketresearchworld.net/; accessed 27.8.10)

$2 \mathrm{~A}$ further area to be debated beyond this article is the choice of nostalgia; sites of memory are likely to be positively selective. We choose the 'good bits' and leave aside the 'bad'. How does that skew our biographical representation of ourselves? 